\title{
NGHIÊN CÚU MỐI LIÊN QUAN CỦA NỒNG ĐỘ BNP HUYẾT THANH VÀ hs- cTnI VỚI BIẾN CỐ TÁI NHẬP VIỆN SAU CAN THIỆP ĐỘNG MẠCH VÀNH
} Đoàn Văn Chung ${ }^{1}$ Hoàng Ành Tiến ${ }^{2}$, Hồ Anh Bình ${ }^{3}$

1. Bệnh viện Đa khoa tỉnh Phú Yên

2. Truờng Đại hoc Y Dược Huế 3. Bệnh viện Trung uoong Huế

DOI: $10.47122 / v j d e .2020 .41 .9$

\section{ABSTRACT \\ The Relationship Between BNP And Hs- cTnI Concentrations With Readmission Risk After Percutaneous Coronary Intervention}

Stratification of early risk for early percutaneous coronary intervention strategies. Some recent studies showed that B type sodiumuretic peptide (BNP) is a biomarker with high concentrations in the serum of patients who got acute coronary syndrome and the high-sensivity cardiac Troponin I (hscTnI) also plays a very important role in the diagnosis and prognosis of coronary artery disease with high sensitivity, as well as, the combination of both serum BNP and hs-cTnI concentrations with the PCI Risk Assessmet scale in short-term prognosis cardiovascular event re-hospitalized within 30 days of follow-up. Objective: To evaluate the relationship between BNP and hs-cTnI concentrations with readmission risk after percutaneous coronary intervention. Method: A descriptive, cross-sectional and longitudinal study on 78 patients with acute coronary syndrome (ACS) were performed PCI at Phu Yen General Hospital from April 2017 to August 2018. Results: Using the PCI Risk tool to predict the re-hospitalization event within 30 days of follow-up had good value $(\mathrm{AUC}=0.795,95 \% \mathrm{CI}=0.68-0.87, \mathrm{p}$ $<0.001)$. There was a predictive correlation to the short-term prognosis of a 30-day followup re-admission event between serum BNP, hs-cTnI and a PCI Risk score of three ROC curves. In this study, the PCI Risk scale predicted better than hs-cTnI concentration with $\mathrm{AUC}=0.795,95 \% \mathrm{KTC}=0.68-0.87$, ( $p<0.001)$. Conclusion: The combination of serum BNP concentration, hs-cTnI and the PCI Risk scale can be used to predict 30-day hospitalization events in patients with coronary syndrome intervened with coronary heart syndrome.

Key words: High-sensivity cardiac Troponin I (hs-cTnI), Percutaneous coronary intervention

\section{TÓM TẮT}

Phân tầng nguy cơ sớm để có chiến lược can thiệp động mạch vành sớm. Một số nghiên cứu gần đây cho biết peptide lợi niệu típ B (B type natriuretic peptide: BNP) là một dấu ấn sinh học có nồng độ cao trong huyết thanh của bệnh nhân hội chứng vành cấp và nồng độ Troponin I tim mạch độ nhạy cao (High-sensivity cardiac Troponin I: hs-cTnI) cũng có vai trò rất quan trọng trong chẩn đoán và tiên lượng bệnh ĐMV với độ nhạy cao, cũng như việc khảo sát kết hợp cả hai nồng độ nồng độ $\mathrm{BNP}$ và hs-cTnI huyết thanh với thang điểm PCI Risk Assessmet trong dự báo tiên lượng ngắn hạn biến cố tim mạch tái nhập viện trong 30 ngày theo dõi. Muc tiêu: Đánh giá mối liên quan của nồng độ BNP huyết thanh và hs-cTnIvới biến cố tái nhập viện sau can thiệp động mạch vành. Đối tương và phương pháp nghiên cứu: Nghiên cứu mô tả cắt ngang, theo dõi dọc trong 30 ngày trên 78 bệnh nhân có hội chứng vành cấp nhập viện được chụp và can thiệp động mạch vành tại Bệnh viện Đa khoa tỉnh Phú Yên từ tháng 4 năm 2017 đến tháng 8 năm 2018. Kết quá: Sử dụng công cụ PCI Riskđể dự báo biến cố bệnh nhân tái nhập viện trong 30 ngày theo dõi có gía trị tốt $(\mathrm{AUC}=0,795,95 \%$ $\mathrm{KTC}=0,68-0,87, \mathrm{p}<0,001)$. Có mối liên quan dự báo khả năng tiên lượng ngắn hạn biến cố tái nhập viện trong 30 ngày theo dõi giữa nồng độ BNP huyết thanh, hs-cTnI với thang điểm PCI Risk bằng 03 đường cong 
ROC thì thang điểm PCI Risk dự báo tiên lượng tốt hơn so với nồng độ hs-cTnI với $\mathrm{AUC}=0,795, \quad 95 \% \quad \mathrm{KTC}=0,68-0,87$, ( $\mathrm{p}<0,001)$. Kết luận: Kết hợp nồng độBNP huyết thanh, hs-cTnI với thang điểm PCI Risk có thể được sữ dụng để dự báo biến cố tái nhập viện sau 30 ngày ở $\mathrm{BN}$ hội chứng vành cấp đượ can thiệp ĐMV.

Tù khóa: Troponin I tim mạch độ nhạy cao, can thiệp động mạch vành

Ngày nhận bài: 29/10/2020

Ngày phản biện khoa học: 04/11/2020

Ngày duyệt bài: 11/12/2020

Email: drhoanhbinh@gmail.com

Điện thoại: 0913489896

\section{1. ĐĂT VẤN ĐỀ}

Phân tầng nguy cơ sớm để có chiến lược can thiệp động mạch vành sớm, có biện pháp điều trị phối hợp tối ưu và tiên lượng bệnh [5]. Những bệnh nhân nguy cơ cao thường có xảy ra các biến cố tim mạch và cần phải được điều trị thuốc tích cực và can thiệp sớm. Phân tầng nguy cơ sớm dựa vào đánh giá bệnh sử, khám lâm sàng, điện tâm đồ và các chất chỉ điểm sinh học hoại tử cơ tim, đặc biệt là troponin... Những năm gần đây, nhiều chất chỉ điểm sinh học mới đã và đang được chứng minh về giá trị tiên lượng tử vong hoặc các biến cố tim mạch chính ở bệnh nhân mắc hội chứng vành cấp [8].

Một số nghiên cứu gần đây cho biết peptide lợi niệu típ B (B type natriuretic peptide: BNP) là một dấu ấn sinh học có nồng độ cao trong huyết thanh của bệnh nhân hội chứng vành cấp và nồng độ Troponin $\mathrm{I}$ tim mạch độ nhạy cao (High-sensivity cardiac Troponin I: hs-cTnI) cũng có vai trò rất quan trọng trong chẩn đoán và tiên lượng bệnh động mạch vành với độ nhạy cao [9]. Nhưng sự kêt hợp của hai chất chỉ điểm sinh học này trong tiên lượng các biến cố tim mạch sau can thiệp động mạch vành vẫn chưa được nghiên cứu nhiều và chuyên sâu, cũng như việc khảo sát kết hợp cả hai nồng độ nồng độ $\mathrm{BNP}$ và hs-cTnI huyết thanh với thang điểm PCI Risk Assessmet trong dự báo tiên lượng ngắn hạn biến cố tim mạch tái nhập viện trong 30 ngày theo dõi. Mục tiêu: Đánh giá mối liên quan của nồng độ BNP huyết thanh và hs-cTnIvới biến cố tái nhập viện sau can thiệp động mach vành.

\section{2. ĐỐI TƯợG VÀ PHƯƠNG PHÁP NGHIÊN CÚU}

\section{1. Đối tượng nghiên cứu}

Tất cả những bệnh nhân có hội chứng vành cấp nhập viện được chụp và can thiệp động mạch vành tại Bệnh viện Đa khoa tỉnh Phú Yên từ tháng 4 năm 2017 đến tháng 8 năm 2018

\subsubsection{Tiêu chuẩn chọn bệnh nhân}

Bệnh nhân được đưa vào nghiên cứu phải thỏa mãn các điều kiện sau:

+ Bệnh nhân được chẩn đoán xác định là nhồi máu cơ tim cấp có $\mathrm{ST}$ chênh lên và không có ST chênh lên hoặc cơn ĐTN không ổn định theo khuyến cáo 2015 của Hội tim mạch học Việt Nam về chẩn đoán và điều trị [2].

+ Bệnh nhân và gia đình đồng ý và hợp tác tham gia nghiên cứu .

\subsubsection{Tiêu chuẩn loại trù̀}

- Bệnh nhân không có chỉ định can thiệp động mạch vành

- Đối tượng can thiệp động mạch vành thất bại như không đưa được dây dẫn, bóng, giá đỡ qua tổn thương.

- Các biến chứng xảy ra trong can thiệp hoặc ngay sau can thiệp như bệnh nhân tử vong, cần phẫu thuật cầu nối chủ-vành cấp cứu.

- Có các tình trạng bệnh lý sau: Chấn thương cơ, viêm cơ tim,bệnh van tim, rung nhĩ, bệnh phổi mạn tính, sốc do mọi nguyên nhân, suy thận, bệnh hệ thống, mang máy tạo nhịp, chấn thương hoặc tai biến mạch máu não $<3$ tháng.

- Các bệnh nhân không hợp tác nghiên cứu.

\subsection{Phương pháp nghiên cứu}

Nghiên cứu được tiến hành theo phương pháp nghiên cứu mô tả cắt ngang, theo dõi dọc trong 30 ngày.

\subsection{Thu thập dữ liệu}

Mỗi bệnh nhân trong mẫu nghiên cứu được khảo sát theo phiếu nghiên cứu được 
thiết kế sẵn lần lượt theo quy trình:

- Hành chính: Tên, tuổi, giới, nghề nghiệp, địa chỉ, ngày giờ vào viện, lý do vào viện.

- Tiền sử: Hút thuốc lá, tăng huyết áp, rối loạn lipid, đái tháo đường, nhồi máu cơ tim cũ, bệnh mạch vành đã đặt stent.

- Ghi nhận các kết quả của các xét nghiệm liên quan như: công thức máu, mỡ máu, chức năng thận, điện tâm đồ, siêu âm tim.

- Định lượng nồng độ $\mathrm{BNP}$, hs-cTnI vào thời điểm lúc nhập viện hoặc trước can thiệp và sau can thiệp động mạch vành trong thời gian $24 \mathrm{~h}$.
- Kết quả chụp ĐMV với tổn thương cần chỉ định can thiệp ĐMV .

- Ghi nhận các biến cố chính sau can thiệp 30 ngày

\subsection{Xử lý số liệu}

- Xử lý số liệu theo phương pháp thống kê $\mathrm{y}$ học, sử dụng phần mềm Microsoft Excel và SPSS 20.0.

- Thống kê phân tích : so sánh các tỷ lệ và kiểm định mối liên quan giữa các biến số định tính bằng phép kiểm định chi bình phương. Kết quả khác biệt được xem là có ý nghĩa thống kê với $\mathrm{p}<0,05$.

\section{KẾT QUẢ NGHIÊN CÚU}

Qua nghiên cứu 78 bệnh nhân có hội chứng vành cấp đươc chụp và can thiệp động mạch vành, chúng tôi thu được một số kết quả như sau:

\section{1. Đặc điểm chung nhóm nghiên cứu}

\subsection{1. Đặc điểm chung theo giới tính và tuổi}

Bảng 3.1. Phân bố đối tượng nghiên cứu theo giới tính

\begin{tabular}{|c|c|c|}
\hline Giới tính & Số lượng(n=78) & Tỷ lệ\% \\
\hline Nam & 61 & 78,2 \\
\hline Nữ & 17 & 21,8 \\
\hline Tổng cộng & 78 & 100,0 \\
\hline
\end{tabular}

Nhận xét:Tỷ lệ được can thiệp động mạch vành của nam chiếm đa số hơn so với nữ $(78,2 \%$ so với $21,8 \%$ ).

Bảng 3.2.Phân bố đối tượng nghiên cứu theo nhóm tuổi và giới

\begin{tabular}{|c|c|c|c|c|c|c|}
\hline Giới Nhóm tuổi & $<\mathbf{5 0}$ & $50-70$ & $\geq 70$ & Cộng & Tỷ lệ (\%) & $\mathbf{p}$ \\
\hline Nam & 4 & 40 & 17 & 61 & 78,2 & \multirow{4}{*}{$<0,05$} \\
\hline Nữ & 0 & 7 & 10 & 17 & 21,8 & \\
\hline Cộng & 4 & 47 & 27 & 78 & 100 & \\
\hline Tỷ lệ\% & 5,1 & 60,3 & 34,6 & 100 & & \\
\hline
\end{tabular}

Nhận xét: Tỷ lệ các đối tượng từ 50 tuổi trở lên có chỉ định can thiệp mạch vành chiếm ưu thế $94,9 \%$, trong đó đối tượng từ 50-70 tuổi chiếm tỷ lệ $60,30 \%(\mathrm{p}<0,05)$.

3.1.2. Đặc điểm các thể lâm sàng của đối tự̛ng nghiên cúu

Bảng 3.3. Phân bố các thể lâm sàng của đối tượng nghiên cứu

\begin{tabular}{|c|c|c|c|}
\hline Các thể lâm sàng & Số lượng (n) & Tỷ lệ (\%) & \multirow{2}{*}{ p } \\
\hline NMCTSTCL & 28 & 35,9 & \multirow{2}{*}{$<0,05$} \\
\hline NMKSTCL & 15 & 19,2 & \\
\hline ĐTNKÔĐ & 35 & 44,9 & \\
\hline Tổng & 78 & 100,0 & \\
\hline
\end{tabular}

Nhận xét: Trong các thể lâm sàng, ĐTNKÔĐ chiếm tỷ lệ cao nhất $44.9 \%$; thấp nhất NMKSTCL chiếm tỷ lệ $19.2 \%(\mathrm{p}<0,05)$ 


\subsection{3. Đặc điểm siêu âm tim của đối tượng nghiên cứu}

Bảng 3.4. Đặc điểm phân suất tống máu của đối tượng nghiên cứu

\begin{tabular}{|c|c|c|c|}
\hline \multirow{3}{*}{ Chỉ số } & Chỉ số (\%) & Số lượng n (\%) & \multirow{2}{*}{ p } \\
\hline \multirow{3}{*}{ EF } & $<30$ & $0(0,0 \%)$ & \multirow{3}{*}{$<0,05$} \\
\cline { 2 - 3 } & $30-39$ & $5(6,4 \%)$ & \\
\cline { 2 - 3 } & $40-50$ & $39(50,0 \%)$ & \\
\cline { 2 - 3 } & $>50$ & $34(43,6 \%)$ & \\
\hline
\end{tabular}

Nhận xét:Phân suất tống máuđối tượng nghiên cứu có $\mathrm{EF}<50 \%$ chiếm tỷ lệ $56,4 \%, \mathrm{EF}>50 \%$ chiếm tỷ lệ 43,6\%. $(\mathrm{p}<0,05)$.

3.1.4. Đặc điểm lâm sàng theo phân độ qua thang điểm Killip

Bảng 3.5. Phân độ theo thang điểm Killip

\begin{tabular}{|c|c|c|c|}
\hline Phân độ Killip & Tần suất & Tỷ lệ\% & \multirow{2}{*}{ p } \\
\hline Độ I & $\mathbf{8}$ & $\mathbf{1 0 , 3}$ & \multirow{2}{*}{$<0,05$} \\
\hline Độ II & $\mathbf{2 6}$ & $\mathbf{3 3 , 3}$ & \\
\hline Độ III & $\mathbf{7}$ & $\mathbf{8 , 9}$ & \\
\hline Độ IV & $\mathbf{2}$ & $\mathbf{2 , 6}$ & \\
\hline
\end{tabular}

Nhận xét: Phần lớn đối tượng nghiên cứu nằm ở độ II Killip 33,3\%. Có 02 trường hợp có phân độ IV 2,6\% $(\mathrm{p}<0,05)$.

3.1.5. Đặc điểm tổn thương động mạch vành của đối tượng nghiên cứu

Bảng 3.6. Phân bố số nhánh tổn thương theo kết quả chụp động mạch vành

\begin{tabular}{|c|c|c|}
\hline Số nhánh tổn thương & Số lượng(n) & Tỷ lệ (\%) \\
\hline 1 nhánh & 38 & 48,7 \\
\hline 2 nhánh & 23 & 29,5 \\
\hline 3 nhánh & 17 & 21,8 \\
\hline Tổng cộng & 78 & 100,0 \\
\hline
\end{tabular}

Nhận xét: Bệnh nhân có tổn thương 1 nhánh động mạch vành chiếm tỷ lệ cao nhất $48,7 \%$. Tổn thương 3 nhánh chiếm tỷ lệ thấp nhất $21,8 \%$.

Bảng 3.7. Phân bố vị trí tổn thương động mạch vành

\begin{tabular}{|c|c|c|}
\hline Nhánh tổn thương & Số lượng(n) & Tỷ lệ (\%) \\
\hline RCA & 54 & 69,2 \\
\hline LM & 1 & 1,3 \\
\hline LAD & 51 & 65,4 \\
\hline LCx & 29 & 37,2 \\
\hline
\end{tabular}

Nhận xét: Tỷ lệ tổn thương động mạch vành phải chiếm cao nhất $69,2 \%$, tiếp đến là tổn thương động mạch liên thất trước $65,4 \%$. Tổn thương thân chung chiếm tỷ lệ thấp nhất $1,3 \%$.

3.2. Liên quan giữa nồng độ BNP huyết thanh và hs-cTnI với biến cố tái nhập viện trong 30 ngày sau can thiệp

\subsubsection{Biến cố tái nhập viện trong 30 ngày theo dõi}

Bảng 3.8. Tỷ lệ biến cố tái nhập viện trong 30 ngày theo dõi

\begin{tabular}{|l|c|c|c|}
\hline \multicolumn{1}{|c|}{ Nhóm } & Số lượng (n) & Tỷ lệ $\mathbf{( \% )}$ & p \\
\hline Không có biến cố & 66 & 84,6 & \multirow{2}{*}{$<0,01$} \\
\hline Có biến cố & 12 & 15,4 & \\
\cline { 1 - 3 } Tổng cộng & 78 & 100,0 & \\
\hline
\end{tabular}


3.2.2. Dụ báo biến cố tái nhập viện trong 30 ngày theo dõi bằng công cụ "PCI RISK ASSESSMEN"

Bảng 3.9. Tỷ lệ dự báo biến cố tái nhập viện trong 30 ngày theo dõi

\begin{tabular}{|c|c|c|c|}
\hline $\begin{array}{c}\text { Tỷ lệ dụ̣ báo bệnh nhân tái } \\
\text { nhập viện }\end{array}$ & Số lượng (n) & Tỷ lệ (\%) & \multirow{2}{*}{ p } \\
\hline Nhóm 1: $<9 \%$ & 3 & 3,8 & \multirow{2}{*}{01} \\
\hline Nhóm 2: $9 \%-21 \%$ & 61 & 78,2 & \\
\hline Nhóm 3: $>21 \%$ & 14 & 17,9 & \\
\hline Tổng số & 78 & 100,0 & \\
\hline
\end{tabular}

Nhận xét: Dự báo tái nhập viện trong 30 ngày theo dõi ở nhóm 2 chiếm tỷ lệ cao nhất $78,2 \%$, thấp nhất ở nhóm $1(3,8 \%)$, tỷ lệ ở các nhóm dự báo trong 30 ngày có ý nghĩa thống kê $(\mathrm{p}<0,01)$.

3.2.3. Mối tuơng quan giữa nồng độ BNP huyết thanh, hs-cTnI với biến cố tái nhập viện sau 30 ngày can thiệp.

Bảng 3.10. Mối tương quan giữa nồng độ BNP huyết thanh, hs-cTnI với biến cố tái nhập viện sau 30 ngày can thiệp

\begin{tabular}{|c|c|c|c|}
\hline \multirow[b]{2}{*}{ Chỉ số } & \multirow[b]{2}{*}{ Giá trị } & \multicolumn{2}{|c|}{ Biến cố tái nhập viện } \\
\hline & & $\begin{array}{c}\text { Không có biến cố } \\
(n=66)\end{array}$ & $\begin{array}{c}\text { Có biến cố } \\
(n=12)\end{array}$ \\
\hline \multirow{2}{*}{$\begin{array}{c}\text { BNP } \\
(\mathrm{pg} / \mathrm{ml})\end{array}$} & Trước CT & $261,33 \pm 369,15$ & $595,79 \pm 860,10$ \\
\hline & Sau CT & $273,60 \pm 335,43$ & $1641,15 \pm 2442,32$ \\
\hline \multicolumn{2}{|c|}{$\mathrm{p}$} & $>0,05$ & $<0,05$ \\
\hline \multirow{2}{*}{$\begin{array}{c}\text { hs-cTnI } \\
\text { (pg/ml) }\end{array}$} & Trước CT & $656,61 \pm 1718,54$ & $1332,03 \pm 1525,52$ \\
\hline & Sau CT & $1234,18 \pm 1847,36$ & $2724,74 \pm 3017,34$ \\
\hline \multicolumn{2}{|c|}{$\mathrm{p}$} & $>0,05$ & $>0,05$ \\
\hline
\end{tabular}

Nhận xét:

Ở nhóm biến cố tái nhập viện trong 30 ngày theo dõi: nồng độ của BNP huyết thanh sau can thiệp tăng cao so với trước can thiệp lần lượt là $595,79 \pm 860,10$ pg/ml; $1641,15 \pm 2442$ pg/ml, có ý nghĩa thống kê $(\mathrm{p}<0,05)$.

Nhóm không có biến cố: Nồng độ BNP huyết thanh có sự thay đổi không đáng kể trước và sau can thiệp $(\mathrm{p}>0,05)$. Nồng độ hs-cTnI sau can thiệp tăng cao so với trước can thiệp $656,61 \pm 1718,54 \mathrm{pg} / \mathrm{ml} ; 1234,18 \pm 1847,36 \mathrm{pg} / \mathrm{ml}$, sự biến đổi này không có ý nghĩa thống kê $(\mathrm{p}>0,05)$.

Bảng 3.11. Liên quan giữa nồng độ BNP huyết thanh, hs-cTnI sau can thiệp với dự báo tái nhập viện bằng công cụ PCI Rick trong 30 ngày theo dõi

\begin{tabular}{|c|c|c|c|c|}
\hline \multirow[b]{2}{*}{ Chỉ số } & \multicolumn{3}{|c|}{ Tỷ lệ dụ̣ báo tái nhập viện bằng công cụ PCI Rick } & \multirow[b]{2}{*}{$\mathbf{p}$} \\
\hline & $\begin{array}{l}\text { Nhóm 1: } \\
<9 \%\end{array}$ & $\begin{array}{l}\text { Nhóm 2: } \\
9 \%-21 \%\end{array}$ & $\begin{array}{c}\text { Nhóm 3: } \\
>21 \%\end{array}$ & \\
\hline BNP(pg/ml) & $112,16 \pm 135,45$ & $326,81 \pm 401,64$ & $1248,5 \pm 2354,97$ & $<0,05$ \\
\hline hs-cTnI (pg/ml) & $519,06 \pm 776,31$ & $\begin{array}{c}1443,45 \pm 2092,6 \\
2 \\
\end{array}$ & $1753,24 \pm 2429,16$ & $>0,05$ \\
\hline
\end{tabular}

Nhận xét: ở cả 3 nhóm dự báo tiên lượng tỷ lệ tái nhập viện trong 30 ngày bằng công cụ PCI Rick tỷ lệ thuận với nồng độ BNP huyết thanh lần lượt là $112.16 \pm 135.45 \mathrm{pg} / \mathrm{ml} ; 326.81 \pm 401.64$ $\mathrm{pg} / \mathrm{ml} ; 1248.5 \pm 2354.97 \mathrm{pg} / \mathrm{ml}(\mathrm{p}<0,05)$. Không có sự liên quan nồng độ hs-cTnI, $(\mathrm{p}>0,05)$. 


\subsubsection{Khả năng tiên lự̆ng biến cố tái nhập viện trong vòng 30 ngày theo dõi của công cụ PCI RISK}

Bảng 3.12. Giá trị tiên lượng biến cố tái nhập viện trong vòng 30 ngày theo dõi của thang điểm PCI RISK

\begin{tabular}{|c|c|c|c|c|c|}
\hline Biến cĥ́ & $\boldsymbol{A U C}$ & $\boldsymbol{K T C}(\mathbf{9 5 \%})$ & Điểm cắt & Độ nhạy & Độ đặc hiệu \\
\hline $\begin{array}{c}\text { Tái nhập viện trong } \\
\text { 30 ngày }\end{array}$ & 0,795 & $0,68-0,87$ & $>2$ & 66,67 & 90,91 \\
\hline
\end{tabular}

Nhận xét:Thang điểm PCI RISK có khả năng tiên lượng biến cố tái nhập viện trong 30 ngày theo dõi. Giá trị điểm cắt của là $>2$ (tương ứng với độ nhạy là $66,67 \%$ và độ đặc hiệu là $90,91 \%$ ),

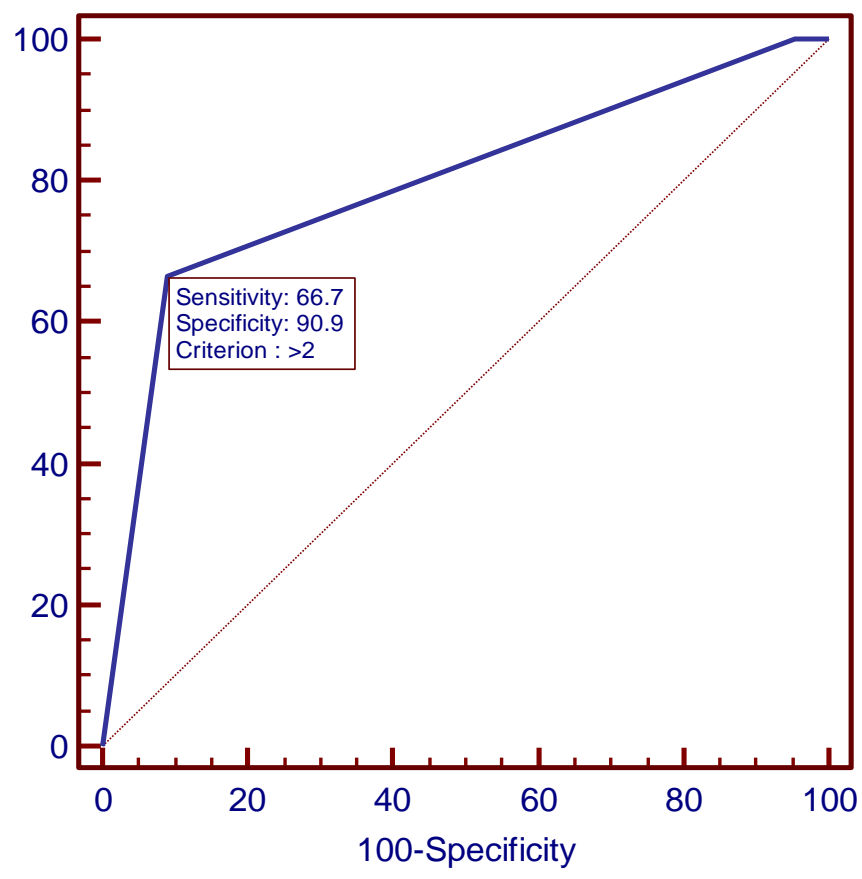

Biểu đồ 3.1. Giá trị tiên lượng bằng công cụ PCI RISK đối với tái nhập viện trong 30 ngày theo dõi

Nhận xét: Thang điểm PCI RISK tại giá trị điểm cắt $>2$, khả năng tiên lượng tái nhập viện trong 30 ngày có độ nhạy 66,7\% \& độ đặc hiệu 90,9\%.

Bảng 3.13. Độ nhạy, độ đặc hiệu, giá trị tiên đoán dương, giá trị tiên đoán âm, tỉ số khả dĩ dương, tỉ số khả dĩ âm của thang điểm PCI RISK

\begin{tabular}{|c|c|c|c|c|}
\hline \multirow{2}{*}{ Giá trị cắt } & \multicolumn{4}{|c|}{ Tái nhập viện trong 30 ngày } \\
\cline { 2 - 5 } & Độ nhạy (\%) & KTC 95\% & Độ đặc hiệu (\%) & KTC 95\% \\
\hline$>1$ & 100,00 & $73,5-100,0$ & 4,55 & $0,9-12,7$ \\
\hline$>2$ & $\mathbf{6 6 , 6 7}$ & $\mathbf{3 4 , 9}-\mathbf{9 0 , 1}$ & $\mathbf{9 0 , 9 1}$ & $\mathbf{8 1 , 3}-\mathbf{9 6 , 6}$ \\
\hline$>3$ & 0,00 & $0,0-26,5$ & 100,00 & $94,6-100,0$ \\
\hline
\end{tabular}

Nhận xét: Thang điểm PCI RISK có giá trị tiên lượng dự báo tái nhập viện trong 30 ngày tại điểm cắt $>2$ (độ nhạy là $66,67 \%$, độ đặc hiệu là 90,91\%). 
Bảng 3.14. Độ nhạy, độ đặc hiệu, giá trị tiên đoán dương, giá trị tiên đoán âm, tỉ số khả dĩ dương, tỉ số khả dĩ âm của PCI RISK

\begin{tabular}{|c|c|c|}
\hline \multirow{2}{*}{ PCI RISK } & \multicolumn{2}{|c|}{ Biến cố tái nhập viện } \\
\cline { 2 - 3 } & Có & Không \\
\hline $\begin{array}{c}\text { PCI RISK > 2 } \\
\text { (Dương tính) }\end{array}$ & 8 & 6 \\
\hline $\begin{array}{c}\text { PCI RISK } \leq 2 \\
\text { (Âm tính) }\end{array}$ & 4 & 60 \\
\hline
\end{tabular}

Độ nhạy

$$
\begin{array}{rr}
66,67 \% & 34,95 \%-89,87 \% \\
90,91 \% & 81,25 \%-96,57 \% \\
7,33 & 3,10-17,36 \\
0,37 & 0,16-0,82 \\
57,14 \% & 28,92 \%-82,24 \% \\
93,75 \% & 84,75 \%-98,23 \%
\end{array}
$$

Độ đặc hiệu

Tỉ số khả dĩ dương

Tỉ số khả dĩ âm

Giá trị tiên đoán dương

Giá trị tiên đoán âm

Nhận xét: Tỷ số khả dĩ dương của công cụ PCI RISK có dự báo tái nhập viện trong 30 ngày theo dõi là 7,33. Có giá trị tiên lượng tốt.

3.2.5. Liên quan nồng độ BNP huyết thanh và hs-cTnI với khả năng tiên lự̛ng biến cố tái nhập viện trong 30 ngày theo dõi

Bảng 3.15. Liên quan khả năng tiên lượng biến cố tái nhập viện trong 30 ngày theo dõi của nồng độ BNP huyết thanh và hs-cTnI

\begin{tabular}{|c|c|c|}
\hline \multirow{2}{*}{$\begin{array}{c}\text { BNP huyết thanh } \\
\text { Hs-cTnI } \\
\text { (pg/ml) }\end{array}$} & \multicolumn{2}{|c|}{ Biến cố tái nhập viện } \\
\cline { 2 - 3 } & $\begin{array}{c}\text { Không } \\
\text { n=66 }\end{array}$ & $\begin{array}{c}\text { Có } \\
\text { n=12 }\end{array}$ \\
\hline $\begin{array}{c}\text { BNP > 232 (+) } \\
\text { hs-cTnI (+) }\end{array}$ & $\begin{array}{c}16 \\
(24,2 \%)\end{array}$ & $\begin{array}{c}11 \\
(91,7 \%)\end{array}$ \\
\hline $\begin{array}{c}\text { BNP> 232 (+) } \\
\text { hs-cTnI (-) }\end{array}$ & $\begin{array}{c}6 \\
(9,1 \%)\end{array}$ \\
\hline $\begin{array}{c}\text { BNP > 232 (-) } \\
\text { hs-cTnI (+) }\end{array}$ & $\begin{array}{c}11 \\
(16,7 \%)\end{array}$ \\
\hline $\begin{array}{c}\text { BNP > 232 (-) } \\
\text { hs-cTnI (-) }\end{array}$ & $\begin{array}{c}33 \\
(50,0 \%)\end{array}$ \\
\hline
\end{tabular}

Nhận xét: Nhóm có biến cố tái nhập viện có BNP dương tính và hs-cTnI dương tính chiếm tỷ lệ cao 91,7\%. Không có biến cố tái nhập viện ở BNP âm tính và hs-cTnI âm tính. 
3.2.6. Liên quan khả năng tiên luọng về dư báo nhập viện trong 30 ngày giữa nồng độ BNP huyết thanh và hs-cTnI với thang điểm PCI RISK

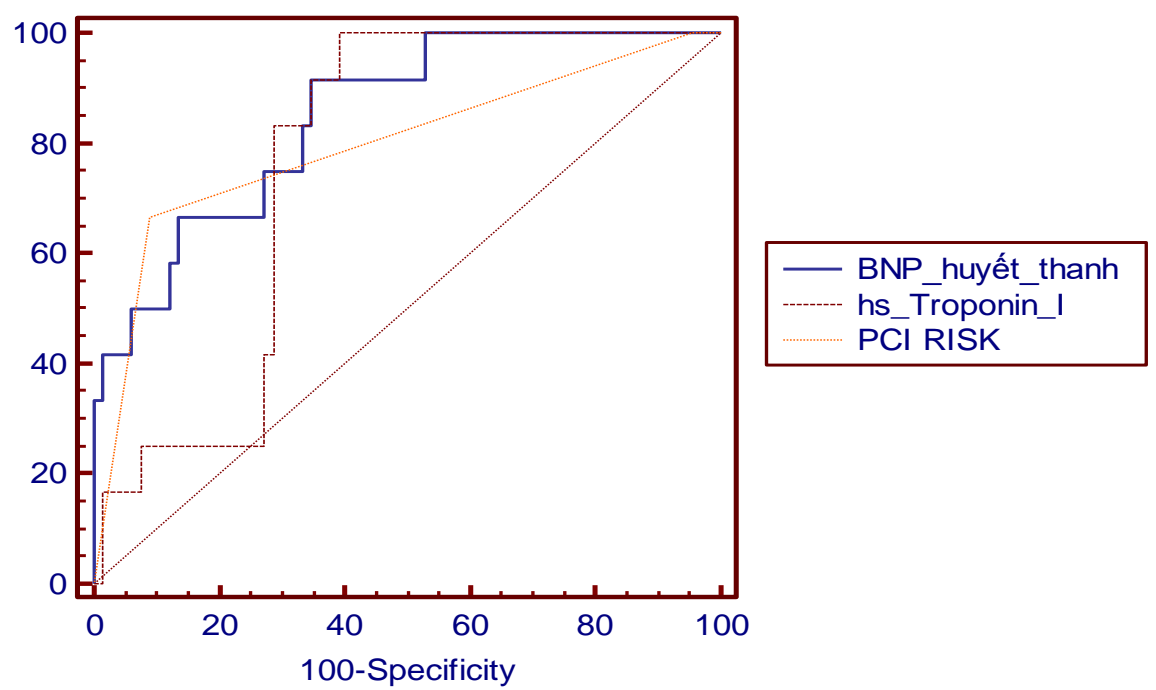

Biểu đồ 3.2. Biểu đồ so sánh đường cong ROC của BNP huyết thanh, hs-cTnI sau can thiệp và thang điểm PCI RISK trong tiên lượng tái nhập viện 30 ngày

Nhận xét: So với nồng độ hs-cTnI, thang điểm PCI RISK có phần chính xác hơn trong tiên lượng biến cố tái nhập viện 30 ngày theo dõi, giúp cải thiện AUC từ 0,764 lên 0,795 . So với thang điểm PCI RISK, nồng độ BNP huyết thanh có cải thiện hơn với AUC từ 0,795 lên 0,848 .

\section{BÀN LUẬN}

4.1. Liên quan nồng độ của BNP huyết thanh và hs-cTnI với với biến cố tái nhập viện trong 30 ngày theo dõi

Trong nghiên cứu của chúng tôi, có sự chênh lệch rõ rệt nồng độ BNP huyết thanh giữa nhóm có và không có biến cố tim mạch. Nồng độ BNP huyết thanh sau can thiệp ở nhóm có biến cố tim mạch tái nhập viện cao gấp 5 lần so với nhóm không có biến cố $(273.60 \pm 335.43 \mathrm{pg} / \mathrm{ml} \quad$ so $\quad$ với $1641.15 \pm 2442.32 \mathrm{pg} / \mathrm{ml} \mathrm{p}<0,05)$.

Theo tác giả Lê Xuân Túy, nghiên cứu về sự biến đổi nồng độ NT - proBNP huyết tương trước và sau can thiệp động mạch vành cho rằng nồng độ NT-proBNP là một dấu hiệu độc lập với tỷ lệ mắc bệnh lâu dài và tỷ lệ tử vong ở những bệnh nhân bị bệnh mạch vành ổn định và không ổn định (CVD) với điểm cắt cao hơn giá trị dự báo suy tim $138 \mathrm{pg} / \mathrm{ml}$ so với $107 \mathrm{pg} / \mathrm{ml}$. Sự gia tăng nồng độ NTproBNP, ngay cả trong bối cảnh không có kết quả cận lâm sàng mắc bệnh tim mạch $(\mathrm{ECG}$, Siêu âm tim) là tiên lượng biến cố tim mạch trong tương lai [4].

Nồng độ hs-cTnI sau can thiệp tăng so với trước can thiệp $656,61 \pm 1718,54 \mathrm{pg} / \mathrm{ml}$; $1234,18 \pm 1847,36 \mathrm{pg} / \mathrm{ml}$, sự biến đổi này không có ý nghĩa thống kê ( $\mathrm{p}>0,05)$. Một số nghiên cứu cho thấy các thế hệ xét nghiệm Troponin đặc hiệu cho cơ tim (Troponin I và Troponin $\mathrm{T}$ ) ngày càng được cải thiện giúp tối ưu hóa việc chẩn đoán và theo dõi điều trị HCVC. Xét nghiệm Troponin I độ nhạy cao được khuyến cáo sử dụng vì tính chất chính xác, cho phép đánh giá nồng độ Troponin tim ở từng giới riêng biệt, ít bị ảnh hưởng bởi bệnh lý thận. 
Hiện nay có nhiều nghiên cứu ứng dụng các thang điểm trong tiên lượng ngắn hạn, dài hạn bệnh nhân Hội chứng vành cấp. Chẳng hạn như GRACE, PURSUIT,PURSUIT phối hợp CRP huyết thanh... Rất ít đề tài nghiên cứu ứng dụng công cụ PCI Risk trong tiên lượng ngắn hạn, dài hạn Hội chứng vành cấp được can thiệp mạch vành . Theo nghiên cứu của chúng tôi, sử dụng công cụ PCI Risk để dự báo tiên lượng tỷ lệ tái nhập viện trong 30 ngày theo dõi sau can thiệp so sánh với tỷ lệ có biến cố tái nhập viện dựa vào 2 chất chỉ điểm như vừa nêu trên. Kết quả là nồng độ BNP huyết thanh sau can thiệp biến đổi tăng dần lần lượt ở 03 nhóm có ý nghĩa thống kê $(\mathrm{p}<0,05)$. Đối với hs-cTnI sự biến đổi này không có ý nghĩa thống kê(p $>0,05)$.

\subsection{Biến cố tái nhập viện trong 30 ngày theo dõi bằng nồng độ $\mathrm{BNP}$ huyết thanh và hs-cTnI.}

Về biến cố tim mạch tái nhập viện trong 30 ngày theo dõi,nghiên cứu của chúng tôi nhóm không có biến cố tim mạch tái nhập viện chiếm tỷ lệ $(84,6 \%)$, nhóm có biến cố (15,4\%). Tại bệnh viện đa khoa tỉnh Phú Yên, theo kết quả nghiên cứu của Nguyễn Thị Mộng Ngọc, tỷ lệ có ít nhất một biến cố tim mạch tại viện là $62,2 \%$, trong đó $30,6 \%$ sốc tim, 53,1\% suy tim tại viện, 26,5\% loạn nhịp nguy hiểm, 6,1\% NMCT mới/tái phát và $19,4 \%$ tử vong. Có $54,1 \%$ có biến cố tim mạch 30 ngày, trong đó 29,6\% tái nhập viện trong vòng 30 ngày, $24,5 \%$ tử vong trong vòng 30 ngày (kể cả tử vong tại viện). Tử vong tại viện của nhóm NMCTSTCL là $18,7 \%$, không có $\mathrm{BN}$ nào thuộc nhóm này tử vong sau xuất viện tính đến thời điểm 30 ngày. Đặc biệt, cả $5 \mathrm{BN}$ tử vong sau xuất viện đều là tử vong tại nhà và đều thuộc nhóm HCVCKSTCL [3].

Theo nghiên cứu của Granger trên 11.389 BN HCVC, tỷ lệ tử vong tại viện chỉ có 4,6\%. Theo quả điều tra của Morrow từ kho dữ liệu InTIME II gồm 15.078 BN NMCTSTCL, tỷ lệ tử vong 30 ngày là $6,7 \%$ [10]. Theo nghiên cứu của Gale dựa trên kho dữ liệu MINAP, tỷ lệ tử vong tại viện của $\mathrm{BN} \mathrm{HCVC}$ là $8,6 \%$; tỷ lệ tử vong 30 ngày của nhóm HCVCKSTCL là $8,9 \%$, của nhóm NMCTSTCL là 12,3\% [7]. Trong nghiên cứu của Trần Viết An [1] tỷ lệ tử vong 30 ngày của $\mathrm{HCVC}$ là $5,5 \%$, trong đó tử vong ở nhóm NMCTSTCL là $6,9 \%$ và nhóm HCVCKSTCL là 4,3\% (p=0,701).

Nhóm nghiên cứu của chúng tôi không có tỷ lệ tử vong và tỷ lệ biến cố tim mạch tái nhập viện rất thấp có lẽ vì bệnh nhân được can thiệp mạch vành tại đơn vị của chúng tôi hầu hết đã được điều trị dùng thuốc tiêu sợi huyết tại viện hoặc trong trường hợp cấp cứu. Trong nghiên cứu InTIME II, 26,2\% được can thiệp mạch vành trong thời gian nằm viện [10]. Ngoài ra, tiêu chí đánh giá biến cố 30 ngày trong nghiên cứu của chúng tôi hơi khác so với các tác giả nên không thể so sánh trực tiếp các tỷ lệ này. Sở dĩ chúng tôi chọn các tiêu chí này để đánh giá vì đây là những biến cố cơ bản và có tính chất quyết định tiên lượng ngắn hạn và dài hạn ở bệnh nhân được can thiệp mạch vành.

\subsection{Sử dụng công cụ thang điểm PCI} RISK ở bệnh nhân can thiệp động mạch vành để dự báo tiên lượng tái nhập viện

Công cụ này giúp dự báo những rủi ro trong và sau can thiêp động mạch vành. Chúng tôi sử dụng kết quả dự báo sau can thiệp nguy cơ tái nhập viện trong 30 ngày theo dõi để nghiên cứu. Về dự báo tái nhập viện trong 30 ngày của thang điểm PCI RISK được phân thành 03 nhóm: nhóm 1: $<9 \%$; nhóm 2: 9-21\%; nhóm 3: > 21\%. Kết quả của chúng tôi có sự khác biệt ở 03 nhóm dự báo tỷ lệ tái nhập viện nhóm 2 chiếm tỷ lệ cao nhất 78,2\%, thấp nhất 3,8\% (ở nhóm 1).

Thực tế lâm sàng có nhiều thang điểm dùng để tiên lượng ngắn hoặc dài hạn ở bệnh nhân có hội chứng vành cấp. Chẳng hạn sử dụng thang điểm PURSUIT trong nghiên cứu của Yan, trung vị của điểm PURSUIT là 7 , các tứ phân vị là 4 và 10 ; tỷ lệ tử vong tại viện theo các nhóm nguy cơ thấp, trung bình và cao lần lượt là $0,3 \%, 1 \%$ và $4,7 \%$. Theo Gonçalves, tỷ lệ tử vong/NMCT 30 ngày theo các phân nhóm nguy cơ lần lượt là $6,5 \%$ (PURSUIT $<10$ điểm), 3,6\% (PURSUIT 1012 điểm), 5,5\% (PURSUIT 13-14 điểm) và $12,9 \%$ (PURSUIT $>14$ điểm). Theo nghiên 
cứu của Trần Như Hải ở $\mathrm{BN}$ HCVC, nhóm PURSUIT $<10$ điểm có tỷ lệ biến cố (tử vong/NMCT/ĐTNKÔĐ) 14 ngày và 30 ngày lần lượt là $22,73 \%$ và $36,36 \%$; nhóm $10-12$ điểm có tỷ lệ biến cố là $31,25 \%$ và $21,88 \%$; nhóm 13-14 điểm có tỷ lệ biến cố là $41,03 \%$ và $25 \%$; nhóm $>14$ điểm có tỷ lệ biến cố là $50 \%$ và $48,39 \%$. Theo nghiên cứu của chúng tôi không có tỷ lệ tử vong trong 30 ngày theo dõi và tỷ lệ tái nhập viện cũng ở mức thấp so với các thang điểm của các nghiên cứu trong nước. Điều này cũng phù hợp vì đối tượng nghiên cứu của chúng tôi là ở nhóm bệnh nhân có hội chứng mạch vành được can thiệp.

4.4. Khả năng tiên lượng biến cố tái nhập viện trong vòng 30 ngày theo dõi của nồng độ BNP huyết thanh, hs-cTnI sau can thiệp 24 giò̀

Theo nghiên cứu của chúng tôi. Khi khảo sát diện tích dưới đường cong ROC (AUC) của nồng độ BNP huyết thanh tiên lượng bệnh nhân tái nhập viện trong 30 ngày theo dõi, chúng tôi thấy rằng, nồng độ $\mathrm{BNP}$ huyết thanh có giá trị tương đối tốt $(\mathrm{AUC}=0.848$, $\mathrm{p}<0,05)$, Giá trị điểm cắt nồng độ $\mathrm{BNP}$ huyết thanh trong tiên lượng tái nhập viện 30 ngày là $>232 \mathrm{mg} / \mathrm{L}$. Khi khảo sát diện tích dưới đường cong ROC (AUC) của nồng độ hscTnI tiên lượng bệnh nhân tái nhập viện trong 30 ngày theo dõi, chúng tôi thấy rằng, nồng độ hs-cTnI có giá trị tương đối tốt (ÁUC $=0.764, p<0,05)$, Giá trị điểm cắt nồng độ hs-cTnI trong tiên lượng tái nhập viện 30 ngày là $>689,6 \mathrm{pg} / \mathrm{ml}$.

Nghiên cứu của Fournier J.A và cs (2008) ở 68 bệnh nhân được đặt stent trần và khảo sát nồng độ của Troponin $\mathrm{T}$ và hs-CRP trước can thiệp và sau can thiệp những khoảng thời gian 8 giờ, 24 giờ và 30 ngày và theo dõi trung bình trong 16,6 tháng với các biến cố tim mạch lớn là tử vong, nhồi máu cơ tim không tử vong, tái can thiệp mạc vành. Kết quả thu được cho thấy hs-CRP tăng có ý nghĩa ở 24 giờ $(\mathrm{p}=0.05)$ và 30 ngày $(\mathrm{p}<0.02)$ sau đặt stent. Vùng bên dưới đường cong ROC sau 30 ngày có độ nhạy $80 \%$, độ đặc hiệu $72 \%$ cho tiên đoán các biến cố tim mạch lớn. Tỷ lệ sống sót sau 12 tháng không xuất hiện bất kỳ biến cố tim mạch lớn nào cao hơn ở nhóm có hs-CRP $\leq 2,5 \mathrm{ng} / \mathrm{L}$ so với nhóm có hs-CRP > 2,5 ng/L ( $\mathrm{p}=0.04)$. Tác giả kết luận đo nồng độ hs-CRP sau đặt stent 30 ngày có thể hữu ích cho việc tiên đoán các biến cố tim mạch muộn [6].

4.5. Khả năng tiên lượng biến cố tái nhập viện trong vòng 30 ngày theo dõi của thang điểm PCI RISK

Trong nghiên cứu của chúng tôi, thang điểm PCI Riskcó giá trị tiên đoán tái nhập viện trong 30 ngày theo dõi với $\mathrm{AUC}=0.795$, $95 \% \mathrm{KTC}=0.68-0.87$.

Kết quả nghiên cứu Nguyễn Thị Mộng Ngọc, thang điểm PURSUIT có giá trị tốt trong tiên đoán tử vong tại viện $(\mathrm{AUC}=0,727$, 95\% KTC $=0.628-0.812, \mathrm{p}<001)$, biến cố chung tại viện $(\mathrm{AUC}=0,776,95 \% \quad \mathrm{KTC}=$ $0,681-0,854, p<0,001)$. Thang điểm PURSUIT cũng có giá trị tiên đoán tử vong 30 ngày tốt $(\mathrm{AUC}=0,750,95 \% \mathrm{KTC}=0,652-0,832, \mathrm{p}<$ $0,001)$, kết quả tương tự đối với tiên lượng biến cố chung 30 ngày $(\mathrm{AUC}=0,700,95 \%$ $\mathrm{KTC}=0,600-0,789, \mathrm{p}<0,01)$. Thang điểm GRACE có giá trị tiên đoán tử vong tại viện cao $(\mathrm{AUC}=0,86,95 \% \quad \mathrm{KTC}=0,77-0,92$, $\mathrm{p}<0,001)$; kết quả tương tự đối với tiên lượng biến cố tim mạch chung tại viện $(\mathrm{AUC}=0,88$, $95 \% \mathrm{KTC}=0,80-0,94, \mathrm{p}<0,001)$. Thang điểm GRACE có giá trị tiên đoán tử vong 30 ngày cũng rất tốt $(\mathrm{AUC}=0,84,95 \% \mathrm{KTC}=0,75$ $0,91, \mathrm{p}<0,001)$, kết quả tương tự đối với tiên lượng biến cố chung 30 ngày ( $\mathrm{AUC}=0,79,95 \%$ KTC 0,70-0,87, p< 0,001) [3].

4.6. Mối liên quan nồng độ BNP huyết thanh và hs-cTnI với của thang điểm $\mathrm{PCI}$ RISK trong dự báo biến cố tái nhập viện trong 30 ngày theo dõi

Kết quả nghiên cứu Nguyễn Thị Mộng Ngọc, so với thang điểm PURSUIT, thang điểm CRP\& PURSUIT tiên lượng tốt hơn biến cố tại viện (AUC từ 0,776 lên 0,879 , $\triangle \mathrm{AUC}=0,103$ với $\mathrm{p}<0,01)$; tiên lượng tốt hơn biến cố 30 ngày (AUC từ 0,700 lên 0,806 , $\triangle \mathrm{AUC}=0,106$ với $\mathrm{p}<0,001)$. Mô hình kết hợp theo hai mức giá trị điểm cắt của $\mathrm{CRP}$ và điểm PURSUIT trong tiên lượng tử vong 30 ngày (mô hình PURSUIT+CRP). So sánh tỷ lệ biến 
cố giữa các phân nhóm nguy cơ theo mô hình PURSUIT+CRP cho thấy rằng ở nhóm nguy cơ thấp $(\mathrm{CRP}<8,6 \mathrm{ng} / \mathrm{L}$ và $\mathrm{PURSUIT}<14)$ không có $\mathrm{BN}$ nào tử vong, $26,3 \%$ có biến cố tại viện và $10,5 \%$ có biến cố 30 ngày. Khi khảo sát tỷ lệ phân nhóm lại giữa hai mô hình, cho thấy sự phân tầng nguy cơ lại theo mô hình PURSUIT+CRP giúp phân nhóm lại hợp lý hơn trong $25,51 \%$ trường hợp đối với tử vong tại viện $(\mathrm{p}<0,001)$ và $25,79 \%$ đối với tử vong 30 ngày $(\mathrm{p}<0,001)$ so với phân tầng nguy cơ theo thang điểm PURSUIT đơn thuần. Tóm lại, sự kết hợp nồng độ CRP huyết thanh với hai thang điểm nguy cơ GRACE và PURSUIT đã giúp cung cấp thêm rất nhiều thông tin về tiên lượng các biến cố tim mạch ngắn hạn ở $\mathrm{BN} \mathrm{HCVC}$ [3].

Theo nghiên cứu của chúng tôi, khi so sánh nồng độ BNP huyết thanh, hs-cTnI với thang điểm PCI Risk dự báo tiên lượng trong 30 ngày bằng biểu đồ 03 đường cong ROC thì so với nồng độ hs-cTnI, thang điểm PCI RISK có phần chính xác hơn trong tiên lượng biến cố tái nhập viện 30 ngày theo dõi, giúp cải thiện AUC từ 0,764 lên 0,795 . So với thang điểm PCI RISK, nồng độ BNP huyết thanh có cải thiện hơn với AUC từ 0,795 lên 0,848 .

\section{KẾT LUẬN}

- Sử dụng cồng cụ PCI Riskđể dự báo biến cố bệnh nhân tái nhập viện trong 30 ngày theo dõi có gía trị tốt (AUC $=0,795,95 \% \mathrm{KTC}=$ $0,68-0,87, \mathrm{p}<0,001)$.

- Có mối liên quan dự báo khả năng tiên lượng ngắn hạn biến cố tái nhập viện trong 30 ngày theo dõi giữa nồng độ BNP huyết thanh, hs-cTnI với thang điểm PCI Risk bằng 03 đường cong ROC thì thang điểm PCI Risk dự báo tiên lượng tốt hơn so với nồng độ hs-cTnI với $\mathrm{AUC}=0,795,95 \% \mathrm{KTC}=0,68-0,87$, $(\mathrm{p}<0,001)$.

\section{TÀI LIÊU THAM KHẢO}

1. Trần Viết An, Trần Hữu Dàng, Huỳnh Văn Minh, Nguyễn Cửu Lợi, Lê Thị Bích Thuận (2010), "Nồng độ NT-proBNP huyết thanh và thang điểm nguy cơ GRACE trong tiên lượng ngắn hạn ở $\mathrm{BN}$ hội chứng vành cấp", Kỷ yếu Hội nghị tim mạch Miền trung Tây nguyên mở rộng lần thứ VI, Phu truoong Tim Mạch Hoc, số 58/2011, tr.248-263.

2. Phạm Gia Khải và cs. (2008), "Can thiệp động mạch vành qua da", Khuyến cáo về các bệnh lý tim mạch và chuyển hóa giai đoạn 2008 của Hộ Tim mạch học Việt Nam.

3. Nguyễn Thị Mộng Ngọc (2015), Nghiên cưu úng dụng thang điểm GRACE và PURSUIT phối hợp CRP huyết thanh trong tiên luợng ngắn hạn bệnh nhân Hội chứng vành cấp, Luận án CKII, Đại học Y Dược Huế.

4. Lê Xuân Túy (2014), Sụ biến đổi nồng độ NT - proBNP huyết turong truóc và sau can thiệp động mạch vành qua da, Luận án chuyên khoa II, ĐH Y Dược Huế

5. Cannon CP, Weintraub WS, Demopoulos LA, et al (2001), "Comparison of early invasive and conservative strategies in patients with unstable coronary syndromes treated with the glycoprotein IIb/IIIa inhibitor tirofiban", $N$ Engl $J$ Med, 344, pp.1879-1887.

6. Fournier J.A. et al. (2008), "The high sensitivity C-reactive protein level one month after bare-metal coronary stenting may predict late adverse events", Rev Esp Cardiol, 81, pp.313-316.

7. Gale CP, Manda S, et al (2009), "Evaluation of risk scores for risk stratification of acute coronary syndromes in the Myocardial Infarction National Audit Project (MINAP) database", Heart; 95(3), pp.221-7.

8. Jernberg $\mathrm{T}$, Jamesa $\mathrm{S}$, Lindahl $\mathrm{B}$, et al (2004), "Natriuretic peptides in unstable coronary artery disease", Eur Heart J, 25, pp.1486-1493.

9. Mitsunobu Kitamura et al. (2013), "Highsensitivity cardiac troponin $\mathrm{T}$ for earlier diagnosis of acute myocardial infarction in patients with initially negative troponin $\mathrm{T}$ test - Comparison between cardiac markers", Journal of Cardiology, Vol.62, pp.336-342. 